Jurnal Keperawatan Silampari

Volume 2, Nomor 2, Juni 2019

e-ISSN: 2581-1975

p-ISSN: 2597-7482

DOI: https://doi.org/10.31539/jks.v2i2.508

IDMERpe

\title{
DIAGNOSA PREEKLAMPSIA PADA IBU HAMIL MENGGUNAKAN SISTEM INFORMASI BERBASIS WEB
}

\author{
Fajaria Nur Aini ${ }^{1}$, Melyana Nurul Widyawati ${ }^{2}$, Bedjo Santoso $^{3}$ \\ Program Studi D3 Kebidanan, Poltekkes Kemenkes Semarang ${ }^{1}$ \\ Program Pascasarjana, Poltekkes Kemenkes Semarang ${ }^{2,3}$ \\ fajaria.aini@gmail.com ${ }^{1}$
}

\begin{abstract}
ABSTRAK
Penelitian ini bertujuan untuk menghasilkan sistem diagnosa preeklampsia secara online serta untuk mengetahui perbedaan kecepatan waktu yang dibutuhkan untuk mendiagnosa preeklampsia menggunakan sistem informasi berbasis web dengan sistem manual. Metode penelitian ini adalah menyusun kerangka kerja dengan rancangan penelitian quasi eksperimental dengan post test only with control group. Penelitian ini dilakukan di Puskesmas. Hasil penelitian menunjukkan bahwa mayoritas responden adalah ibu hamil sehat yaitu pada kelompok intervensi sejumlah 20 ibu hamil (30.30\%) dan pada kelompok kontrol sebesar $15 \mathrm{ibu}$ hamil $(22.73 \%)$. Jumlah diagnosa terkecil yaitu pada kasus superimposed preeklampsia. Sistem informasi berbasis web juga mampu meningkatkan kecepatan diagnosa mencapai 7.21\%. Hasil uji statistik dengan menggunakan Independent T-Test didapatkan P-value sebesar $0.041<0.05(\alpha)$. Simpulan, ada perbedaan waktu penegakan diagnosa preeklampsia menggunakan sistem informasi berbasis web dengan sistem manual.
\end{abstract}

Kata Kunci: Diagnosa, Preeklampsia, Sistem Informasi, Web

\section{ABSTRACT}

This study aims to produce a preeclampsia diagnostic system online and to determine the difference in the speed of time required to diagnose preeclampsia using a web-based information system with a manual system. This research method is to arrange a framework with a quasi experimental research design with a post test only with control group. This research was conducted at the Community Health Center. The results showed that the majority of respondents were healthy pregnant women namely in the intervention group of 20 pregnant women (30.30\%) and in the control group of 15 pregnant women $(22.73 \%)$. The smallest number of diagnoses is in the case of superimposed preeclampsia. Web-based information systems are also able to increase diagnostic speeds to $7.21 \%$. Statistical test results using the Independent $T$-Test obtained a P-value of $0.041<0.05(\alpha)$. Conclusion, there is a difference in the time of diagnosis of preeclampsia using a web-based information system with a manual system.

Keywords: Diagnosis, Preeclampsia, Information Systems, Web 


\section{PENDAHULUAN}

Preeklampsia merupakan salah satu penyebab terbanyak kematian ibu dan bayi di seluruh dunia terutama di negara berkembang. World Health Organization (WHO) memperkirakan kasus preeklampsia tujuh kali lebih tinggi di negara berkembang daripada di negara maju (Allen et al, 2014, Park et al, 2014, Park et al, 2015, English et al, 2015). Prevalensi preeklampsia di negara maju adalah 1,3-6\%, sedangkan di negara berkembang adalah 1,8-18\%. Insiden preeklampsia di Indonesia sendiri adalah 128.273/tahun atau sekitar 5,3\%. Kecenderungan yang ada dalam dua dekade terkahir ini tidak terlihat adanya penurunan yang nyata terhadap insiden preeklampsia, berbeda dengan insiden infeksi yang semakin menurun sesuai dengan perkembangan temuan antibiotik(Wibowo et al., 2016). Tidak lengkapnya data riwayat ibu hamil yang selama ini terjadi menyebabkan penentuan diagnosa yang tidak tepat dan berakibat kesalahan pada pengambilan keputusan(Wójtowicz et al., 2016)

Pemanfaatan teknologi informasi seperti pesan teks (SMS), pesan video, panggilan suara dan konektivitas internet dapat meningkatkan pelayanan kesehatan dalam proses pengiriman data dan hasil kesehatan, kepatuhan pengobatan, kepatuhan pemantauan pasien (Shiferaw et al, 2016). Hasil temuan dalam survei terkait dalam deteksi preeklampsia antara lain bidan tidak melakukan anamnesa riwayat kesehatan yang lalu, pemeriksaan fisik dalam kunjungan pertama ANC tidak lengkap (Fatkhiyah, 2015). Selain itu, kurangnya keahlian, peralatan dan laboratorium seringkali menyebabkan tidak terdiagnosanya preeklampsia. Tes skrining sederhana yang tidak membutuhkan akses ke laboratorium akan memiliki dampak signifikan terhadap morbiditas dan kematian akibat preeklampsia (Tagare et al, 2014). Dengan adanya sistem pendukung keputusan klinis akan sangat membantu tenaga kesehatan dalam mengambil keputusan terkait dengan kesehatan pasien karena data yang diperoleh lebih cepat, lengkap dan akurat (Bakibinga et al, 2017, Graham et al, 2016). Penelitian ini menggunakan sistem informasi rule based system untuk diagnosa preeklampsia pada ibu hamil. Sehingga diharapkan data yang dikumpulkan lebih lengkap, lebih efisien, serta mengurangi risiko pengambilan keputusan yang salah.

\section{METODE PENELITIAN}

Rancangan penelitian yang digunakan yaitu quasi eksperimental dengan post test only with control group. Penelitian ini dilakukan di Puskesmas. Teknik sampling yang digunakan adalah non probability sampling dengan purposive sampling, dengan jumlah sampel yaitu 66 responden. Kelompok intervensi $(n=33)$ menggunakan sistem informasi, sedangkan kelompok kontrol $(\mathrm{n}=33)$ dengan menggunakan checklist manual.

Sistem informasi yang dirancang adalah sistem informasi berbasis web. Akses informasi yang terdapat dalam sistem informasi dilakukan secara online sehingga membutuhkan koneksi internet. Prosedur dalam penelitian ini yaitu bidan menginput data serta hasil pemeriksaan ibu hamil, kemudian diproses oleh sistem informasi yang menghasilkan diagnosa preeklampsia. Informasi diagnosa preeklampsia yang terdapat dalam sistem informasi dilakukan validasi dengan 2 orang pakar, dalam hal ini yaitu bidan. Perhitungan uji validitas sistem informasi dilakukan dengan cara menggunakan pengukuran nilai data benar dibagi nilai data keseluruhan dikalikan $100 \%$. 


\section{HASIL PENELITIAN}

Gambaran Diagnosa Preeklampsia Menggunakan Sistem Informasi Berbasis Web dapat dilihat pada gambar di bawah ini:
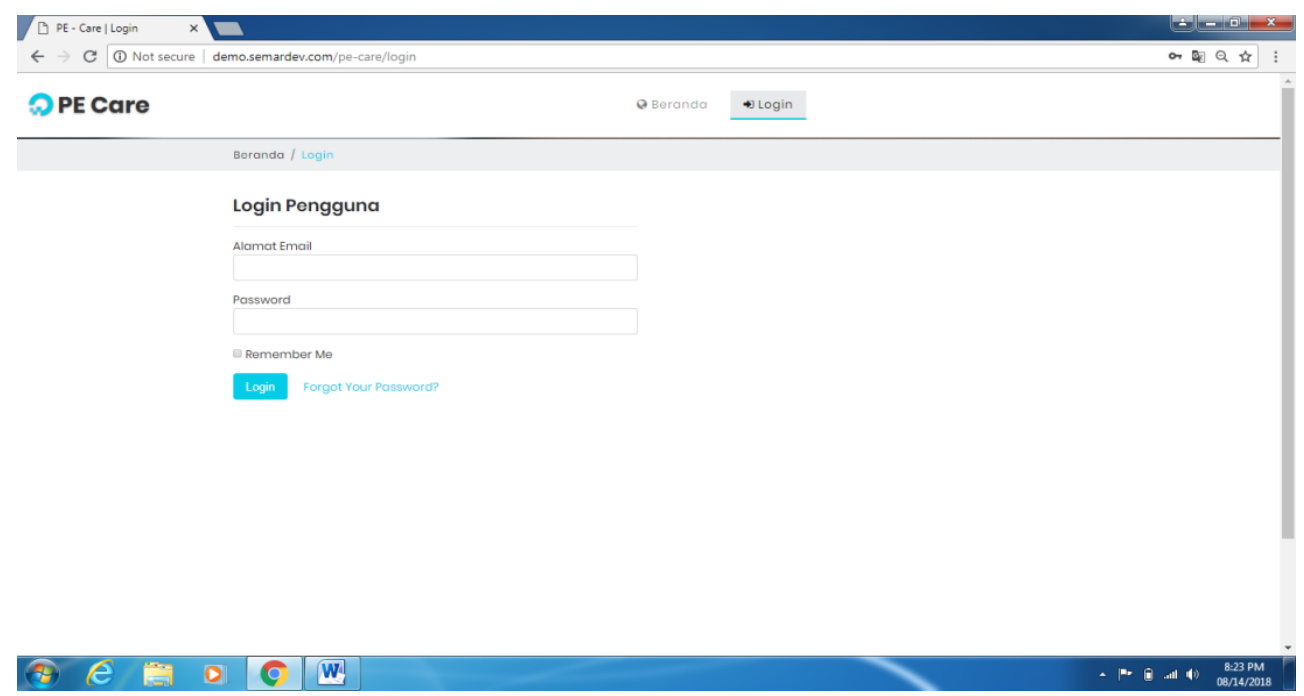

Gambar. 1

Menu $\log I n$

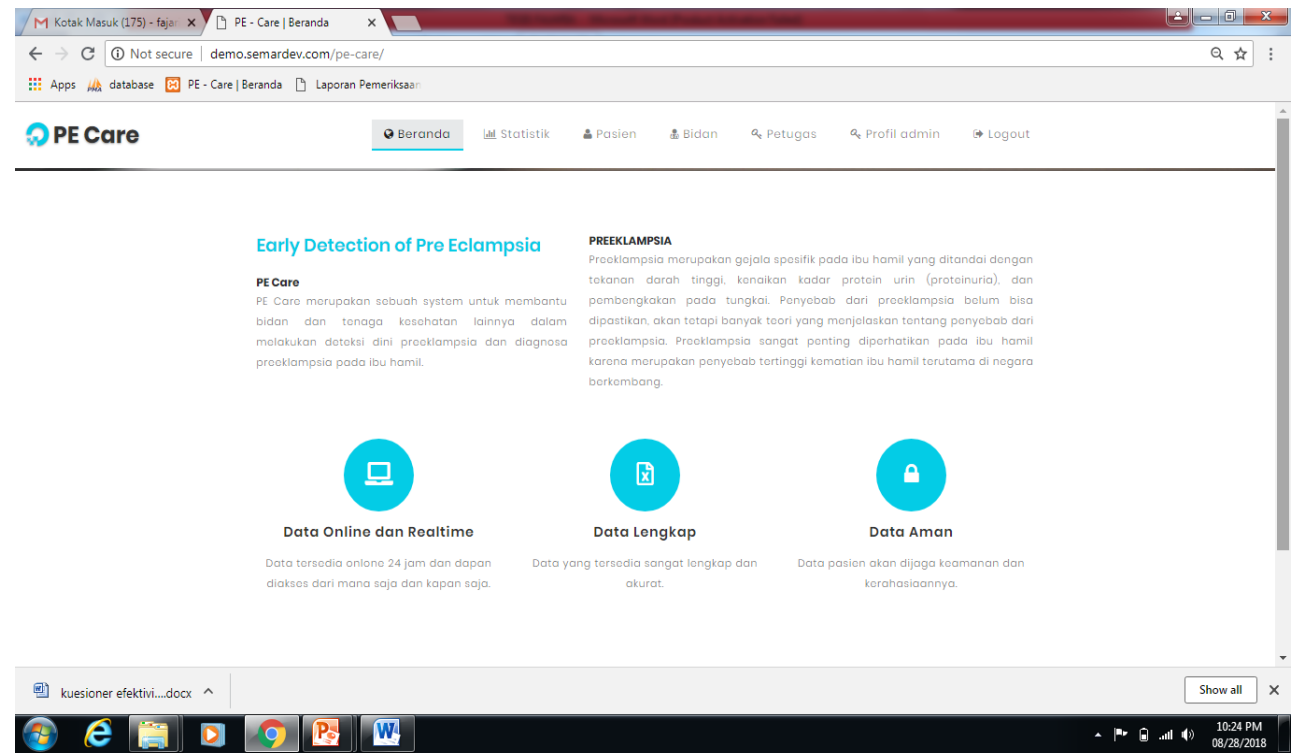

Gambar. 2

Tampilan Menu Beranda 


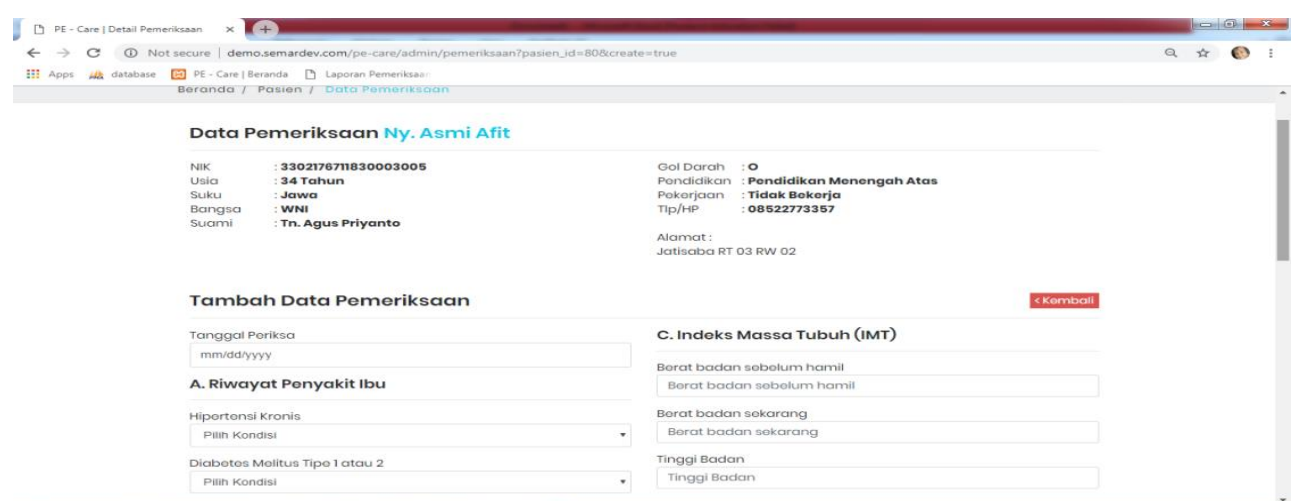

(2) E

Gambar. 3

Menu Input Data dan Pemeriksaan Ibu Hamil

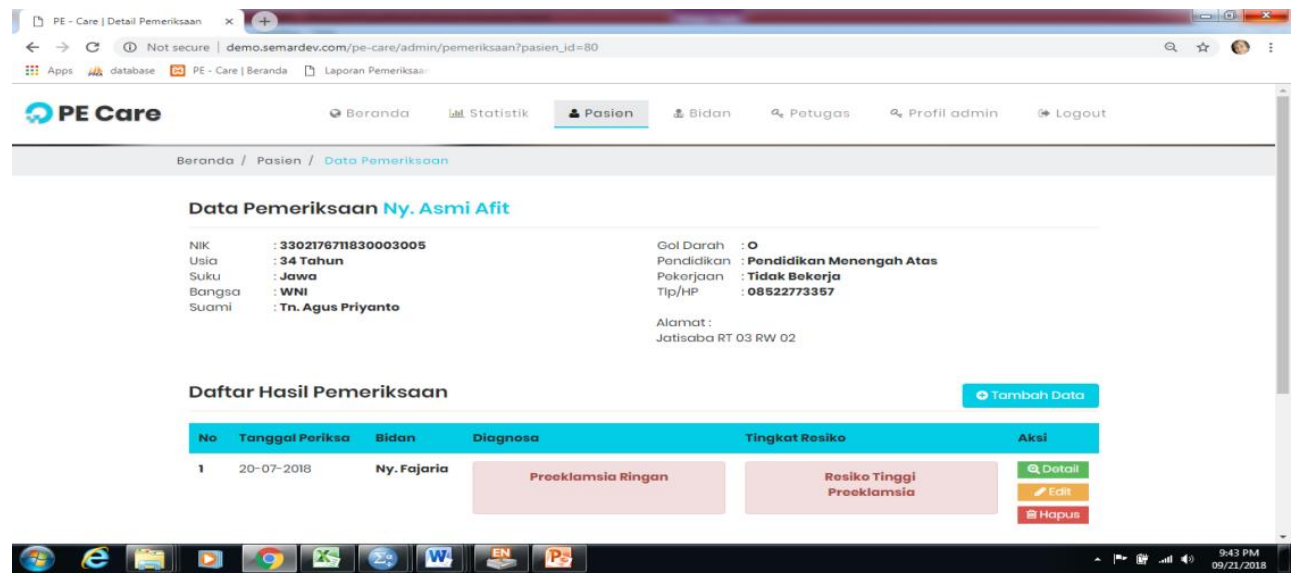

Gambar. 4

Menu output data hasil pemeriksaan ibu hamil

Hasil Diagnosa

Ibu hamil Sehat

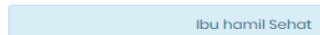

Hasil Diagnosa

Preeklamsia Ringan

Hasil Diagnosa

Preeklamsia Berat

Hasil Diagnosa

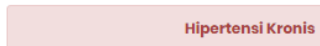

Hasil Diagnosa

Hipertensi Gestasional

Hasil Diagnosa

Superimposed Preeklampsic

Gambar. 5

Hasil Diagnosa 
Gambar 1 menunjukkan menu log in dimana bidan dapat mengakses sistem informasi setelah terdaftar oleh admin. Bidan hanya dapat merubah data pada pasien yang diinputkan bidan tersebut tanpa ada akses perubahan data pada akun bidan yang lain. Akan tetapi bidan dapat mengakses data ibu hamil secara keseluruhan untuk melihat riwayat pemeriksaan ibu hamil yang telah dilakukan sebelumnya. Gambar 2 menunjukkan menu beranda dimana pada menu tersebut terdapat beberapa fitur antara lain statistik, pasien, bidan, petugas dan log out. pada menu statistik bidan dapat melihat jumlah pasien yang telah diinput beserta jumlah kasusnya serta grafik sebaran kasus hasil pemeriksaan. Untuk menambah data pasien bidan dapat mengklik fitur tambah pasien pada menu pasien. Gambar 3 menunjukkan input data ibu hamil dan pemeriksaan. Data yang diinputkan meliputi biodata ibu, riwayat kesehatan ibu, riwayat obstetri, Indeks Massa Tubuh (IMT) dan hasil pemeriksaan. Setelah input dilakukan, maka sistem akan mengolah dan mengeluarkan diagnosa seperti pada gambar 4 dan 5 .

Distribusi frekuensi diagnosa preeklampsia pada ibu hamil dapat dilihat pada tabel 1 di bawah ini:

Tabel. 1

Distribusi Frekuensi Diagnosa

\begin{tabular}{ccccccc}
\hline Diagnosa & \multicolumn{2}{c}{ Manual } & \multicolumn{2}{c}{ Sistem Informasi } & Jumlah & Persentase \\
\cline { 2 - 5 } & Jumlah & Persentase & Jumlah & Persentase & Total & \\
\hline Ibu Hamil Sehat & 23 & $34.85 \%$ & 25 & $37.87 \%$ & 48 & $72.73 \%$ \\
Hipertensi Kronis & 2 & $3.03 \%$ & 1 & $1.51 \%$ & 3 & $4.55 \%$ \\
Hipertensi Gestasional & 2 & $3.03 \%$ & 3 & $4.55 \%$ & 5 & $7.57 \%$ \\
Preeklampsia Ringan & 2 & $3.03 \%$ & 2 & $3.03 \%$ & 4 & $6.06 \%$ \\
Preeklampsia Berat & 3 & $4.55 \%$ & 1 & $1.52 \%$ & 4 & $6.06 \%$ \\
Superimposed Preeklampsia & 1 & $1.52 \%$ & 1 & $1.52 \%$ & 2 & $3.03 \%$ \\
\hline Jumlah & 33 & $50 \%$ & 33 & $50 \%$ & 66 & $100 \%$ \\
\hline
\end{tabular}

Tabel 1 menunjukkan bahwa mayoritas responden adalah ibu hamil sehat yaitu pada kelompok intervensi sejumlah 25 ibu hamil (37.87\%) dan pada kelompok kontrol sebesar $23 \mathrm{ibu}$ hamil (34.85\%). Jumlah diagnosa terkecil yaitu pada kasus superimposed preeklampsia.

Perbedaan waktu kecepatan diagnosa preeklampsia dapat dilihat pada tabel 2 di bawah ini:

Tabel. 2

Perbedaan Waktu Kecepatan Diagnosa Preeklampsia

\begin{tabular}{ccccc}
\hline Kelompok & $\mathrm{N}$ & $\begin{array}{c}\text { Mean } \\
\text { (detik) }\end{array}$ & $S D$ & P-Value \\
\cline { 1 - 4 } Intervensi & 33 & 371.12 & 68.271 & \multirow{2}{*}{0.041} \\
\hline Kontrol & 33 & 400.83 & 88.054 & \\
\hline
\end{tabular}

Tabel 2 menunjukkan bahwa seluruh responden pada kelompok intervensi dilakukan diagnosa preeklampsia menggunakan sistem informasi berbasis web dengan rata-rata lama pemeriksaan yaitu 371.12 detik. Sedangkan pada kelompok kontrol responden 
mendapatkan pemeriksaan dengan sistem manual dengan rata-rata waktu yang diperlukan adalah 400.83 detik. Hasil ini menunjukkan bahwa responden pada kelompok intervensi mengalami waktu pemeriksaan lebih cepat dibandingkan dengan sistem manual, yaitu sebesar $7.21 \%$ lebih cepat. Berdasarkan intepretasi data dapat ditarik kesimpulan bahwa pada waktu penegakan diagnosa kelompok intervensi lebih baik jika dibandingkan dengan kelompok kontrol. Hal ini dapat dilihat dari nilai mean serta standar deviasi kelompok intervensi lebih rendah jika dibandingkan dengan kelompok kontrol. Hasil uji statistik dengan menggunakan Independent T-Test didapatkan $P$-value sebesar $0.041<0.05(\alpha)$, sehingga Ha diterima dan Ho ditolak, dengan kata lain ada perbedaan waktu penegakan diagnosa preeklampsia menggunakan sistem informasi berbasis web dengan sistem manual.

\section{PEMBAHASAN}

Hasil penelitian menunjukkan bahwa mayoritas responden adalah ibu hamil dengan diagnosa ibu hamil sehat yaitu sebanyak sejumlah 25 ibu hamil (37.87\%) pada kelompok intervensi dan pada kelompok kontrol sebesar 23 ibu hamil (34.85\%). Jumlah diagnosa terkecil yaitu pada kasus superimposed preeklampsia.

Hasil uji statistik mean pada kelompok intervensi (sistem informasi) sebesar 371.12 detik dengan standar deviasi 68.271 dan nilai mean pada kelompok kontrol 400.83 detik dengan standar deviasi 88.054. Berdasarkan intepretasi data dapat ditarik kesimpulan bahwa pada waktu penegakan diagnosa kelompok intervensi lebih baik jika dibandingkan dengan kelompok kontrol. Hal ini dapat dilihat dari nilai mean serta standar deviasi kelompok intervensi lebih rendah jika dibandingkan dengan kelompok kontrol. Hasil uji statistik dengan menggunakan Independent T-Test didapatkan $P$-value sebesar $0.041<0.05$ $(\alpha)$, dengan kata lain ada perbedaan waktu penegakan diagnosa preeklampsia menggunakan sistem informasi berbasis web dengan sistem manual. Selain itu berdasarkan distribusi frekuensi waktu dalam melakukan diagnosa preeklampsia pada kelompok intervensi lebih cepat dibandingkan dengan kelompok kontrol. Pada kelompok intervensi rata-rata waktu yang dibutuhkan untuk melakukan diagnosa preeklampsia pada ibu hamil adalah 371.12 detik, sedangkan pada kelompok kontrol 400.83 detik. Hal ini menunjukkan bahwa terjadi peningkatan kecepatan dalam melakukan diagnosa preeklampsia menggunakan sistem informasi berbasis web sebesar $7.21 \%$.

Preeklampsia merupakan salah satu penyebab terbanyak kematian ibu dan bayi di seluruh dunia terutama di negara berkembang. Preeklampsia adalah sekumpulan gejala yang timbul pada wanita hamil, bersalin dan nifas yang terdiri dari hipertensi, edema dan protein uria tetapi tidak menunjukkan tanda-tanda kelainan vaskuler atau hipertensi sebelumnya, sedangkan gejalanya biasanya muncul setelah kehamilan berumur 28 minggu atau lebih (Padila, 2016). Health Organization (WHO) memperkirakan kasus preeklampsia tujuh kali lebih tinggi di negara berkembang daripada di negara maju (Allen et al, 2014; Park et al, 2014; Park et al, 2015; English et al, 2015). Prevalensi preeklampsia di negara maju adalah 1,3-6\%, sedangkan di negara berkembang adalah 1,8-18\%. Insiden preeklampsia di Indonesia sendiri adalah 128.273/tahun atau sekitar 5,3\% (Allen, 2014).

Eklampsia adalah salah satu penyebab kematian ibu dan bayi terbesar di dunia. Preeklampsia merupakan masalah yang serius dan memiliki tingkat kompleksitas yang tinggi. Besarnya masalah ini bukan hanya karena preeklampsia berdampak pada ibu saat hamil dan melahirkan, namun juga menimbulkan masalah pasca persalinan akibat disfungsi 
endotel di berbagai organ, seperti risiko penyakit kardiometabolik dan komplikasi lainnya. Dampak jangka panjang juga dapat terjadi pada bayi yang dilahirkan dari ibu dengan preeklampsia, seperti berat badan lahir rendah akibat persalinan prematur atau mengalami pertumbuhan janin terhambat, serta turut menyumbangkan besarnya angka morbiditas dan mortalitas perinatal. Penyakit hipertensi dalam kehamilan merupakan penyebab tersering kedua morbiditas dan mortalitas perinatal. Bayi dengan berat badan lahir rendah atau mengalami pertumbuhan janin terhambat juga memiliki risiko penyakit metabolik pada saat dewasa. Berbagai faktor penyebab seringkali dijumpai seringkali ditemukan secara bersamaan menyebabkan angka kematian ibu karena preeklampsia, diantaranya status gizi, higiene, sanitasi, pola hidup, jangkauan ke pelayanan kesehatan, status ekonomi, pendidikan, tingkat pengetahuan tentang hamil risiko tinggi, tradisi sosial budaya dan geografis serta status reproduksi seperti kehamilan risiko tinggi yang tidak disadari masalahnya oleh ibu hamil (Wibowo et al, 2016).

Identifikasi awal kehamilan dengan risiko tinggi preeklampsia sangat penting dilakukan oleh bidan untuk mencegah angka morbiditas dan mortalitas ibu dan bayi dan dampak panjang yang diakibatkan oleh preeklampsia. Skrining risiko terjadinya preeklampsia sangat penting dilakukan pada wanita hamil sejak awal kehamilannya (Wright et al., 2015, Wibowo et al., 2016).

Pada penelitian ini, diagnosa preeklampsia akan dilakukan dengan menggunakan sistem informasi berbasis web. Teknologi mobile berpotensi menjembatani sistemik kesenjangan yang dibutuhkan untuk memperbaiki akses dan penggunaan kesehatan layanan, terutama di kalangan populasi terlayani. Di seluruh dunia, penggunaan perangkat mobile dan/atau elektronik mendukung praktik medis, kesehatan masyarakat dan penelitian (mHealth) (Bakibinga et al, 2017). Salah satu tujuan telehealth adalah untuk meningkatkan akses yang lebih komprehensif dan meningkatkan kualitas layanan kesehatan. Dimana pasien dengan mudah memberikan kabar tentang kondisi kesehatannya setelah proses pemulihan ataupun saat mula terkena sakitnya kepada perawat, yang telah dipercaya dalam memberikan pelayanan kepada pasiennya (Padila, 2018).

Diagnosa preeklampsia dibutuhkan data pemeriksaan yang lengkap. Seperti pada penelitian yang menyebutkan bahwa pemeriksaan ibu hamil sangat penting dilakukan karena merupakan suatu cara untuk memperoleh data subjektif dan objektif yang nantinya akan digunakan untuk merumuskan diagnosa. Jika pemeriksaan tidak lengkap maka data yang diperoleh kurang akurat dan bidan akan kesulitan dalam merumuskan suatu masalah (Abu et al, 2017).

Perbedaan rata-rata waktu penegakan diagnosa preeklampsia menggunakan sistem informasi berbasis web dibandingkan dengan sistem manual memiliki perbedaan yang tidak terlalu jauh. Hal ini dikarenakan untuk melakukan diagnosa (baik dengan sistem informasi berbasis web maupun dengan sistem manual) dibutuhkan pemeriksaan laboratorium protein urin. Pemeriksaan protein urin dilakukan terpadu dengan pemeriksaan laboratorium lainnya di laboratorium oleh petugas khusus laboratorium. Lama dalam melakukan pemeriksaan laboratorium protein urin tergantung pada antrian pemeriksaan laboratorium lainnya, sehingga hasilnya menjadi tidak jauh berbeda walaupun tetap lebih cepat jika menggunakan sistem informasi berbasis web. Senada dengan hal tersebut, penelitian yang dilakukan di Kenya pada tahun 2015 oleh Warren et al mengungkapkan bahwa dengan adanya pengembangan sistem informasi guna mendukung pengambilan keputusan klinis waktu 
yang dibutuhkan oleh tenaga kesehatan dan tenaga sukarelawan lebih cepat. Kecepatan dalam pelaporan hasil pemeriksaan kepada klien akan mempengaruhi kualitas dari tempat pelayanan kesehatan tersebut (Warren et al, 2015). Sistem informasi juga memberikan kemudahan dalam hal pengaksesan data pasien menjadi lebih cepat (Utami, Nuryati, 2015).

Kecepatan dalam melakukan diagnosa preeklampsia sangat diperlukan agar penderita cepat mendapatkan penanganan yang tepat serta penderita tidak mengalami komplikasi yang disebabkan karena preeklampsia. Menurut Rana (2014) preeklampsia sangat berhubungan dengan angka kematian dan kesakitan ibu. Penderita preeklampsia berisiko mengalami komplikasi yang parah seperti eklampsia, ruptur hati, stroke, edema paru, gagal ginjal dan perdarahan. Selain itu preeklampsia menjadi penyebab pertumbuhan janin terhambat, kelahiran prematur. Anak-anak yang lahir dari ibu dengan preeklampsia memiliki peningkatan risiko displasia bronkopulmoner dan cerebral palsy yang disebakan karena kelahiran prematur. Kualitas hidup juga akan menurun dan meningkatkan risiko depresi pasca melahirkan (Rana et al, 2014).

\section{SIMPULAN}

Sistem informasi berbasis web dapat melakukan diagnosa preeklampsia lebih cepat jika dibandingkan dengan sistem manual, yaitu sebesar $7.21 \%$. Hal ini dibuktikan dengan uji statistik independent T-test dengan p-value $0.041 \quad(<0.05)$. Sehingga dapat disimpulkan bahwa terdapat perbedaan kecepatan waktu deteksi dini preeklampsia menggunakan sistem informasi berbasis web dengan sistem manual.

\section{SARAN}

1. Bagi pendidikan dan bagi perkembangan ilmu pengetahuan

Perlu dilakukan soasialisasi mengenai inovasi diagnosa menggunakan sistem informasi berbasis web untuk mempercepat proses pemeriksaan ibu hamil.

2. Bagi Dinas Kesehatan

Perlu dilakukan sosialisasi dan pendekatan dengan dinas kesehatan agar sistem dapat diimplementasikan guna meningkatkan cakupan diagnosa preeklampsia.

3. Bagi peneliti selanjutnya

Perlu dikembangkan sistem sampai dengan proses rujukan agar rujukan kasus diagnosa juga bisa lebih cepat dan tepat penanganannya. 


\section{DAFTAR PUSTAKA}

Abu, A. D. K. H., Kusumawati, Y. \& Werdani, K. E. (2017). Hubungan Karakteristik Bidan dengan Mutu Pelayanan Antenatal Care Berdasarkan Standar Operasional. Jurnal Kesehatan Masyarakat Andalas, 10, 94-100

Allen, R., Rogozinska, E., Sivarajasingam, P., Khan, K. S. \& Thangaratinam, S (2014). Effect of Diet-And Lifestyle-Based Metabolic Risk-Modifying Interventions on Preeclampsia: A Meta-Analysis. Acta Obstetricia Et Gynecologica Scandinavica, 93, 973-985

Bakibinga, P., Kamande, E., Omuya, M., Ziraba, A. K. \& Kyobutungi, C. (2017). The Role of A Decision-Support Smartphone Application in Enhancing Community Health Volunteers' Effectiveness to Improve Maternal and Newborn Outcomes in Nairobi, Kenya: Quasi-Experimental Research Protocol. Bmj Open, 7, E014896

English, F. A., Kenny, L. C. \& Mccarthy, F. P (2015). Risk Factors and Effective Management Of Preeclampsia. Integrated Blood Pressure Control, 8, 7

Fatkhiyah, N. (2015). Motivasi, Kualitas Supervisi dan Kepatuhan Bidan dalam Mendeteksi Preeklampsia. Jurnal Kesehatan Masyarakat, 10, 195-202

Graham, W., Woodd, S., Byass, P., Filippi, V., Gon, G., Virgo, S., Chou, D., Hounton, S., Lozano, R., Pattinson, R. \& Singh, S. (2016). Diversity and Divergence: The Dynamic Burden of Poor Maternal Health. The Lancet, 388, 2164-2175

Padila, P. (2016). Asuhan Keperawatan Maternity II. Yogyakarta: Nuha Medika

Padila, P., Lina, L., Febriawati, H., Agustina, B., \& Yanuarti, R. (2018). Home Visit Berbasis Sistem Informasi Manajemen Telenursing. Jurnal Keperawatan Silampari, 2(1), 217-235. https://doi.org/https://doi.org/10.31539/jks.v2i1.305

Padila, P., Amin, M., \& Rizki, R. (2018). Pengalaman Ibu dalam Merawat Bayi Preterm yang Pernah dirawat di Ruang Neonatus Intensive Care Unit Kota Bengkulu. Jurnal Keperawatan Silampari, 1(2), 1-16. https ://doi.org /https: //doi.org /10.31539 /jks. v1i2.82

Park, H. J., Kim, S. H., Jung, Y. W., Shim, S. S., Kim, J. Y., Cho, Y. K., Farina, A., Zanello, M., Lee, K. J. \& Cha, D. H. (2014). Screening Models Using Multiple Markers for Early Detection of Late-Onset Preeclampsia in Low-Risk Pregnancy. Bmc Pregnancy and Childbirth, 14(35)

Park, H. J., Shim, S. S. \& Cha, D. H. (2015) Combined Screening for Early Detection of Pre-Eclampsia. International Journal of Molecular Sciences, 16, 17952-17974

Rana, S., Karumanchi, S. A. \& Lindheimer, M. D. (2014). Angiogenic Factors in Diagnosis, Management, and Research in Preeclampsia. Hypertension, 63, 198-202

Shiferaw, S., Spigt, M., Tekie, M., Abdullah, M., Fantahun, M. \& Dinant, G.-J. (2016). The Effects Of A Locally Developed Mhealth Intervention on Delivery and Postnatal Care Utilization; A Prospective Controlled Evaluation Among Health Centres in Ethiopia. Plos One, 11, E0158600

Tagare, H. D., Rood, K. \& Buhimschi, I. (2014). A. An Algorithm to Screen for Preeclampsia Using A Smart Phone. Healthcare Innovation Conference (Hic). IEEE, $52-55$

Utami, D. H. N. \& Nuryati, S. (2015). Evaluasi Ketepatan Reseleksi Diagnosis Utama Sebelum dan Setelah Verifikasi pada Kasus Pasien BPJS di Rumah Sakit Hidayah Boyolali. Universitas Gadjah Mada 
Warren, C. E., Abuya, T., Kanya, L., Obare, F., Njuki, R., Temmerman, M. \& Bellows, B. (2015). A Cross Sectional Comparison of Postnatal Care Quality in Facilities Participating in A Maternal Health Voucher Program Versus Non-Voucher Facilities In Kenya. Bmc Pregnancy And Childbirth, 15, 153

Wibowo, Irwinda, Frisdiantiny, Karkata, Mose, Chalid. (2016). Pedoman Nasional Pelayanan Kedokteran Diagnosis dan Tatalaksana Pre-Eklampsia, Jakarta, Perkumpulan Obstetri dan Ginekologi Indonesia Himpunan Kedokteran Feto Maternal

Wójtowicz, A., Żywica, P., Stachowiak, A. \& Dyczkowski, K. (2016). Solving the Problem of Incomplete Data in Medical Diagnosis Via Interval Modeling. Applied Soft Computing, 47, 424-437

Wright, D., Syngelaki, A., Akolekar, R., Poon, L. C. \& Nicolaides, K. H. (2015). Competing Risks Model in Screening for Preeclampsia by Maternal Characteristics and Medical History. American Journal of Obstetrics \& Gynecology, 213, 62. E1-62. E10 